\title{
Genetic polymorphisms of Fas (CD95) and FasL (CD178) in human longevity: studies on centenarians
}

M Pinti ${ }^{1}$, L Troiano ${ }^{1}$, M Nasi ${ }^{1}$, L Moretti ${ }^{1}$, E Monterastelli ${ }^{1}$,

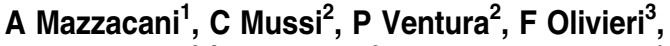
C Franceschi ${ }^{3,4}$, G Salvioli ${ }^{2}$ and A Cossarizza ${ }^{*, 1}$

${ }^{1}$ Department of Biomedical Sciences, University of Modena and Reggio Emilia, via Campi 287, 41100 Modena, Italy

2 Department of Internal Medicine, University of Modena and Reggio Emilia, Ospedale Estense, 41100 Modena, Italy

${ }^{3}$ Department of Gerontological Studies, INRCA, via Birarelli 8, 60121 Ancona, Italy

${ }^{4}$ Department of Experimental Pathology, University of Bologna, via San Giacomo 12, 40126 Bologna, Italy

* Corresponding author: Andrea Cossarizza, MD PhD, Department of Biomedical Sciences, Section of General Pathology, via Campi, 287, 41100 Modena, Italy. Tel: +39 059 2055.415; Fax: +39 059 2055.426; E-mail: cossariz@unimo.it

Received 2.5.01; revised 1.10.01; accepted 2.10.01

Edited by PH Krammer

\begin{abstract}
Apoptosis plays a crucial role in immunosenescence, as also evidenced by the increased expression of Fas in lymphocytes from aged people. However, little is known about the genetic regulation of Fas and its ligand, FasL. We have studied their polymorphisms in 50 centenarians and 86 young donors living in Northern Italy. The first Fas polymorphism, at position -670 , has in Caucasian a heterozigosity of $51 \%$; the second, at -1377 position, has the wild type allele (G) with a very high frequency $(83 \%)$ respect to the mutant allele. Genotype and allele distribution for both polymorphisms were similar in controls and centenarians. Similar results were found as far as two FasL polymorphisms (IVS2nt-124 and IVS3nt169) are concerned. On the whole, our data suggest that Fas and FasL polymorphisms, as well as their haplotypes, are unlikely to be associated with successful human longevity.

Cell Death and Differentiation (2002) 9, 431-438. DOI: 10.1038/sj/ $\operatorname{cdd} / 4400964$
\end{abstract}

Keywords: apoptosis; CD95/Apo-1/Fas gene; CD178/FasL gene polymorphism; aging

Abbreviations: RFLP, restriction fragment length polymorphism; ASA, allele specific amplification; ACRS, amplification created restriction site

\section{Introduction}

Apoptosis is involved in a large number of physiological functions and pathological processes, including the homeostasis of the immune system. An important role of apoptosis can be predicted in aging, where changes in the balance between cell proliferation/activation and cell loss are frequent. $^{1-3}$ Such changes determine some characteristic features of immunosenescence, such as thymic involution, skewing of $\mathrm{T}$ cell repertoire, accumulation of memory/effector $\mathrm{T}$ cells and autoimmune phenomena, among others. ${ }^{4-8}$

One of the most important apoptotic pathways is that triggered by CD95 (Fas/Apo-1), a type 1 transmembrane protein belonging to the tumor necrosis factor (TNF) receptor superfamily. ${ }^{9}$ Fas regulates several immune processes, including selection of $\mathrm{T}$ cell repertoire, deletion of self-reactive cells and cytotoxicity against target cells or tissues, among others. ${ }^{10-14}$ Fas is present on the cell surface as a monomeric protein, and can be bound by its natural ligand, called Fas ligand (FasL, CD178), a protein member of TNF superfamily. ${ }^{15}$ Cross-linking of Fas by FasL leads to trimerization of death domain (DD) of Fas in the inner membrane surface; the trimeric Fas recruits an adapter protein, the Fas associated DD (FADD), by homotypic protein-protein interaction, forming a deathinducing signaling complex (DISC). FADD then recruits procaspase 8 to the DISC by homotypic interaction between their death effector domains (DED). Procaspase 8 is autolytically cleaved into active caspase 8 , which activates caspase 3 , and starts a complex signaling pathway that leads to apoptosis. ${ }^{16,17}$

Peripheral naïve $T$ cells express little or no cell surface Fas, whereas activated memory $\mathrm{T}$ cells express relatively high levels of Fas. This has been linked to the higher susceptibility of memory cells to undergo apoptosis, and further underlines the role of Fas in the homeostasis of the immune system. ${ }^{14}$

In the last years, a growing interest has been devoted to studies on the expression of Fas in human aging and longevity, and different authors have shown that the number of Fas+T cells increases with age. ${ }^{18-21}$ Fas expression seems to increase both in $\mathrm{CD}^{+}$and $\mathrm{CD}^{+}$ cells, this increase being present either in naïve $\left(\mathrm{CD} 45 \mathrm{RA}^{+}, \mathrm{CD} 2 \mathrm{~L}^{+}\right.$) or memory $\mathrm{T}$ lymphocytes $\left(\mathrm{CD} 45 \mathrm{RO}^{+}, \mathrm{CD} 2 \mathrm{~L}^{-}\right)$, suggesting that the shift from naïve to memory is not uniquely responsible for this phenomenon. ${ }^{20}$ Such an upregulation, along with a reduced expression of bcl-2, has been correlated to the existence of an age-related increased susceptibility to apoptosis both in CD4 and CD8 T cells. ${ }^{22}$ However, little is known about the molecular mechanism that modifies the expression of Fas in lymphocytes of elderly subjects, nor of its transcriptional regulation, and it is not known whether and how aging influences the activity of this gene.

Recently, two polymorphisms have been identified in the 5 flanking region of the human Apo-1/Fas gene. ${ }^{23}$ The first is located $670 \mathrm{bp}$ upstream from the translational start site of the gene, on the binding site of the transcription factors 
STAT. ${ }^{24}$ This polymorphism is an A to $\mathrm{G}$ substitution that creates a restriction site for $M v a l$ and is therefore called Mval restriction fragment length polymorphism (RFLP). This polymorphism is common in the normal Caucasian population, with a frequency of 0.49 for allele $G$ and 0.51 for the allele $A$. The second polymorphism is a $G$ to $A$ substitution at position -1377 with respect to the translational start site, that does not create or delete any restriction site, but abolishes the consensus sequence for binding of transcription factor $\mathrm{SP}-1 .^{25}$ It was reported that the wild-type allele $\mathrm{G}$ has a frequency of 0.87 in normal Caucasian population, whereas allele $A$ has a frequency of 0.13 .

Concerning the FasL gene, nowadays, no polymorphisms have been identified in the coding region, but two polymorphic sites exist in the second and third intron of the gene. $^{26}$ The first one, named IVS2nt-124, is an A to $G$ substitution in the nucleotide 124 upstream from the first base of the third exon. The second polymorphism, named IVS3nt169, is a deletion of a T at position 169 downstream from the last base of the third exon. It is still not known if these polymorphisms are associated with a different expression of the gene.

In order to ascertain whether the presence of a particular genotype set in the promoter of Fas gene or in FasL introns may contribute to successful aging, we have analyzed the frequency of these polymorphisms in a group of centenarians and young donors living in Northern Italy (Emilia Romagna Region).

\section{Results}

To examine the possible association between the two polymorphisms $(-670$ and -1377$)$ reported for Fas promoter and longevity, a total of 86 young controls and 50 centenarians were genotyped.

The -670 genotype distribution and allele frequencies in young and centenarian subjects are shown in Table 1A. In both groups $A$ and $G$ alleles are in Hardy-Weinberg equilibrium; the heterozygous form of Mval polymorphism was present in $48 \%$ of the centenarians; individuals who were homozygous for $\mathrm{A}$ and $\mathrm{G}$ were $34 \%$ and $18 \%$, respectively. In comparison to young controls, we found a slightly higher percentage of $\mathrm{A} / \mathrm{A}$ genotype; however, the difference between these two populations cannot be considered significant $\left(\chi^{2}=0.840\right.$, with $\left.P=0.657\right)$. Since the gender distribution was different in the group of centenarians, we have analyzed the genotype distribution in the subgroups of males and females. The number of males (six individuals) was clearly too low to allow any statistical analysis; in the case of females (44 donors), we found that the difference in the percentage of $A / A$ subjects between centenarians and controls was more marked (Table 1B), even if such difference did not reach the level of statistical significance $\left(\chi^{2}=3.740\right.$, with $\left.P=0.154\right)$.

The distribution of genotypes and allele frequency of -1377 polymorphism in the same groups is reported in Table 2A. The percentage of G/G homozygous subjects was quite high in control subjects $(76.7 \%)$, and did not differ significantly from percentage we have found in centenarians (88.0\%). Heterozygous subjects were about $21 \%$ of young population, and $12 \%$ in centenarians. Among centenarians, we could not find any subject who was homozygous for the allele $A$, while two subjects in the control group showed this genotype. Also in the subgroup of females, the genotypes and allele frequency do not differ significantly from controls (Table $2 \mathrm{~B}$ ).

Finally, we have analyzed -1377 and -670 genotypes in combination, and have estimated the haplotype frequencies in both populations. The frequency of combined genotypes and haplotypes are reported in Table $3 \mathrm{~A}$ and $B$. The distribution of combined genotypes between centenarians and controls was not significantly different $(P=0.550)$. Some combinations of genotypes were lacking, mainly because of the absence of $A / A$ genotype at position -1377 in centenarians.

The haplotype estimation, analyzed by using a sensitive method, 27 did not evidence any significant difference between the two populations. The highest differences between haplotype frequencies were in those subjects who have the allele $A$ in -1377 position; such differences were mainly due to the absence of centenarians with $A / A$ genotype at position -1377 . In both cases, alleles are not in linkage disequilibrium $(P=0.44$ for centenarians, $P=0.099$ for young donors).

Table 1A Genotype and allele frequency of the -670 polymorphism in young controls and centenarian subjects

\begin{tabular}{|c|c|c|c|c|c|}
\hline & \multicolumn{3}{|c|}{ Genotype } & \multicolumn{2}{|c|}{ Allele frequency } \\
\hline & G/G & G/A & A/A & G & A \\
\hline $\begin{array}{l}\text { Controls }(n=86) \\
\text { Centenarians }(n=50)\end{array}$ & $\begin{array}{c}16(18.6 \%) \\
9(18 \%)\end{array}$ & $\begin{array}{c}47(54.7 \%) \\
24(48 \%) \\
\chi^{2}=0.840 \\
P=0.657\end{array}$ & $\begin{array}{c}23(26.7 \%) \\
17(34 \%)\end{array}$ & $\begin{array}{c}45.9 \% \\
42 \%\end{array}$ & $\begin{array}{c}54.1 \% \\
58 \%\end{array}$ \\
\hline
\end{tabular}

B Genotype and allele frequency of the -670 polymorphism in young controls and centenarian females

\begin{tabular}{|c|c|c|c|c|c|}
\hline & \multicolumn{3}{|c|}{ Genotype } & \multicolumn{2}{|c|}{ Allele frequency } \\
\hline & G/G & G/A & A/A & $\mathbf{G}$ & $\mathbf{A}$ \\
\hline $\begin{array}{l}\text { Controls }(n=36) \\
\text { Centenarians }(n=44)\end{array}$ & $\begin{array}{l}6(16.7 \%) \\
9(20.4 \%)\end{array}$ & $\begin{array}{c}23(63.9 \%) \\
19(43.2 \%) \\
\chi^{2}=3.740 \\
P=0.154\end{array}$ & $\begin{array}{c}7(19.4 \%) \\
16(36.4 \%)\end{array}$ & $\begin{array}{c}48.6 \% \\
42 \%\end{array}$ & $\begin{array}{l}51.4 \% \\
58 \%\end{array}$ \\
\hline
\end{tabular}


Table 2A Genotype and allele frequency of the -1377 polymorphism in young controls and centenarian subjects

\begin{tabular}{|c|c|c|c|c|c|}
\hline & \multicolumn{3}{|c|}{ Genotype } & \multicolumn{2}{|c|}{ Allele frequency } \\
\hline & G/G & G/A & $A / A$ & $\mathbf{G}$ & A \\
\hline $\begin{array}{l}\text { Controls }(n=86) \\
\text { Centenarians }(n=50)\end{array}$ & $\begin{array}{c}66(76.7 \%) \\
44(88 \%)\end{array}$ & $\begin{array}{c}18(20.9 \%) \\
6(12 \%) \\
\chi^{2}=3.087 \\
P=0.214\end{array}$ & $\begin{array}{c}2(2.4 \%) \\
0(0 \%)\end{array}$ & $\begin{array}{c}87.2 \% \\
94 \%\end{array}$ & $\begin{array}{c}12.8 \% \\
6 \%\end{array}$ \\
\hline
\end{tabular}

B Genotype and allele frequency of the -1377 polymorphism in young controls and centenarian females

\begin{tabular}{|c|c|c|c|c|c|}
\hline & \multicolumn{3}{|c|}{ Genotype } & \multicolumn{2}{|c|}{ Allele frequency } \\
\hline & G/G & G/A & A/A & G & A \\
\hline $\begin{array}{l}\text { Controls }(n=36) \\
\text { Centenarians }(n=44)\end{array}$ & $\begin{array}{l}26(72.2 \%) \\
38(86.4 \%)\end{array}$ & $\begin{array}{c}9(25 \%) \\
6(13.6 \%) \\
\chi^{2}=3.081 \\
P=0.214\end{array}$ & $\begin{array}{c}1(2.8 \%) \\
0(0 \%)\end{array}$ & $\begin{array}{l}84.7 \% \\
93.2 \%\end{array}$ & $\begin{array}{l}15.3 \% \\
6.8 \%\end{array}$ \\
\hline
\end{tabular}

Table 3A Fas combined genotype frequency in centenarian and control subjects

\begin{tabular}{|c|c|c|c|}
\hline \multicolumn{2}{|c|}{ Genotype } & \multicolumn{2}{|c|}{ Group } \\
\hline-670 & -1377 & Controls & Centenarians \\
\hline $\begin{array}{l}G / G \\
G / G \\
G / G \\
G / A \\
G / A \\
G / A \\
A / A \\
A / A \\
A / A\end{array}$ & $\begin{array}{l}G / G \\
G / A \\
A / A \\
G / G \\
G / A \\
A / A \\
G / G \\
G / A \\
A / A\end{array}$ & $\begin{aligned} 12 & (13.9 \%) \\
3 & (3.5 \%) \\
1 & (1.2 \%) \\
32 & (37.2 \%) \\
14 & (16.2 \%) \\
1 & (1.2 \%) \\
22 & (25.6 \%) \\
1 & (1.2 \%) \\
0 & \end{aligned}$ & $\begin{array}{c}6(12 \%) \\
3(6 \%) \\
0 \\
22(44 \%) \\
2(4 \%) \\
0 \\
16(32 \%) \\
1(2 \%) \\
0 \\
0\end{array}$ \\
\hline
\end{tabular}

B Haplotype frequency estimation for Fas in control and centenarian subjects. For each frequency, the calculated mean \pm standard deviation is reported

\begin{tabular}{ccr}
\hline Haplotype & Frequency in controls & Frequency in centenarians \\
\hline AA & $2.1 \pm 1.4 \%$ & $1.3 \pm 1.4 \%$ \\
AG & $51.9 \pm 3.9 \%$ & $56.6 \pm 5.0 \%$ \\
GA & $10.6 \pm 2.5 \%$ & $4.7 \pm 2.3 \%$ \\
GG & $35.7 \pm 3.6 \%$ & $37.3 \pm 4.9 \%$ \\
\end{tabular}

We have then analyzed the distribution of two known polymorphisms of FasL gene in the same groups of donors, and studied DNA from 76 young controls and 42 centenarians. As reported in Table $4 A$ and $B$, the distribution of genotypes and allele frequency of IVS2nt124 polymorphism does not show any significant difference between the groups of centenarians and young donors, either considering the whole groups $\left(\chi^{2}=1.254\right.$, with $P=0.263$ ), or considering the female subgroups only $\left(\chi^{2}=1.029\right.$, with $\left.P=0.310\right)$. The same analysis was carried out for the IVS3nt169 polymorphism, and the results are reported in Table $5 \mathrm{~A}$ and $\mathrm{B}$. We have not found any difference between the whole groups $\left(\chi^{2}=0.668\right.$, with $P=0.315)$ as well as between the female subgroups $\left(\chi^{2}=0.491\right.$, with $\left.P=0.782\right)$.

Finally, we have analyzed FasL genotypes in combination, as in the case of Fas polymorphisms, and we have estimated the haplotype frequencies in both populations.
The frequency of combined genotypes are not different between centenarians and controls $(P=0.298)$ as well as haplotype distribution ( $P=0.326)$ (Table $6 \mathrm{~A}$ and $\mathrm{B})$. The only difference is the absence of the haplotype with $G$ in position IVS2nt-124 and delT in IVSnt169 in young controls. As a consequence, the linkage disequilibrium analysis of such a haplotype becomes significant $\left(\chi^{2}=8.579\right.$, with $\left.P=0.003\right)$.

\section{Discussion}

For many years, our group has been studying the biology of centenarians, i.e. those individuals who have been able to reach the extreme limit of human life avoiding the major agerelated diseases, and who are considered the best model of physiological successful aging. ${ }^{28-34}$ The immune system of these exceptional individuals undergoes a complex and profound remodelling, ${ }^{27,28}$ that includes a paradoxical, 
Table 4A Genotype and allele frequency of the IVS2nt-124 FasL polymorphism in young controls and centenarian subjects

\begin{tabular}{|c|c|c|c|c|c|}
\hline & \multicolumn{3}{|c|}{ Genotype } & \multicolumn{2}{|c|}{ Allele frequency } \\
\hline & A/A & $\mathbf{A} / \mathbf{G}$ & $\mathbf{G} / \mathbf{G}$ & A & $\mathbf{G}$ \\
\hline $\begin{array}{l}\text { Controls }(n=77) \\
\text { Centenarians }(n=46)\end{array}$ & $\begin{array}{l}48(62.3 \%) \\
34(73.9 \%)\end{array}$ & $\begin{array}{c}29(37.7 \%) \\
12(26.1 \%) \\
\chi^{2}=1.254 \\
P=0.263\end{array}$ & $\begin{array}{l}0(0 \%) \\
0(0 \%)\end{array}$ & $\begin{array}{l}81.2 \% \\
86.9 \%\end{array}$ & $\begin{array}{l}18.8 \% \\
13.1 \%\end{array}$ \\
\hline
\end{tabular}

B Genotype and allele frequency of the IVS2nt-124 FasL polymorphism in young controls and centenarian females

\begin{tabular}{|c|c|c|c|c|c|}
\hline & \multicolumn{3}{|c|}{ Genotype } & \multicolumn{2}{|c|}{ Allele frequency } \\
\hline & $\mathbf{A} / \mathbf{A}$ & A/G & G/G & $\mathbf{A}$ & $\mathbf{G}$ \\
\hline $\begin{array}{l}\text { Controls }(n=33) \\
\text { Centenarians }(n=39)\end{array}$ & $\begin{array}{l}19(57.6 \%) \\
28(71.8 \%)\end{array}$ & $\begin{array}{c}14(42.4 \%) \\
11(28.2 \%) \\
\chi^{2}=1.029 \\
P=0.310\end{array}$ & $\begin{array}{l}0(0 \%) \\
0(0 \%)\end{array}$ & $\begin{array}{l}78.8 \% \\
85.9 \%\end{array}$ & $\begin{array}{l}21.2 \% \\
14.1 \%\end{array}$ \\
\hline
\end{tabular}

Table 5A Genotype and allele frequency of the IVS3nt-169 FasL polymorphism in young controls and centenarian subjects

\begin{tabular}{|c|c|c|c|c|c|}
\hline & \multicolumn{3}{|c|}{ Genotype } & \multicolumn{2}{|c|}{ Allele frequency } \\
\hline & $\mathrm{T} / \mathrm{T}$ & T/delT & delT/delT & $\mathbf{T}$ & delT \\
\hline $\begin{array}{l}\text { Controls }(n=76) \\
\text { Centenarians }(n=42)\end{array}$ & $\begin{array}{l}55(72.4 \%) \\
33(78.6 \%)\end{array}$ & $\begin{array}{c}15(19.7 \%) \\
7(16.7 \%) \\
\chi^{2}=0.668 \\
P=0.315\end{array}$ & $\begin{array}{l}6(7.9 \%) \\
2(4.8 \%)\end{array}$ & $\begin{array}{l}82.2 \% \\
86.9 \%\end{array}$ & $\begin{array}{l}17.8 \% \\
13.1 \%\end{array}$ \\
\hline
\end{tabular}

B Genotype and allele frequency of the IVS3nt-169 FasL polymorphism in young controls and centenarian females

\begin{tabular}{|c|c|c|c|c|c|}
\hline & \multicolumn{3}{|c|}{ Genotype } & \multicolumn{2}{|c|}{ Allele frequency } \\
\hline & $\mathrm{T} / \mathrm{T}$ & T/delT & delT/delT & $\mathbf{T}$ & delT \\
\hline Controls $(n=33)$ & $25(75.7 \%)$ & $5(15.2 \%)$ & $3(9.1 \%)$ & $83.3 \%$ & $16.7 \%$ \\
\hline Centenarians $(n=39)$ & $30(76.9 \%)$ & $\begin{array}{c}7(17.9 \%) \\
\chi^{2}=0.491 \\
P=0.782\end{array}$ & $2(5.2 \%)$ & $85.9 \%$ & $14.1 \%$ \\
\hline
\end{tabular}

Table 6A FasL combined genotype frequency in centenarian and control subjects

\begin{tabular}{cccc}
\hline & Genotype & & \multicolumn{2}{c}{ Group } & Centenarians \\
\hline IVS2nt-124 & IVS3nt169 & Controls & $23(54.7 \%)$ \\
A/A & T/T & $29(38.2 \%)$ & $6(14.3 \%)$ \\
A/A & T/delT & $12(15.8 \%)$ & $1(2.4 \%)$ \\
A/A & delT/delT & $6(7.9 \%)$ & $10(23.8 \%)$ \\
A/G & T/T & $26(34.2 \%)$ & $1(2.4 \%)$ \\
A/G & T/delT & $3(3.9 \%)$ & $1(2.4 \%)$ \\
A/G & delT/delT & 0 & 0 \\
G/G & T/T & 0 & 0 \\
G/G & T/delT & 0 & 0 \\
G/G & delT/delT & 0 & $\chi^{2}=6.083$ \\
& & & $P=0.298$ \\
\end{tabular}

B Haplotype frequency estimation for FasL polymorphisms in control and centenarian subjects. For each frequency, the calculated mean \pm standard deviation is reported

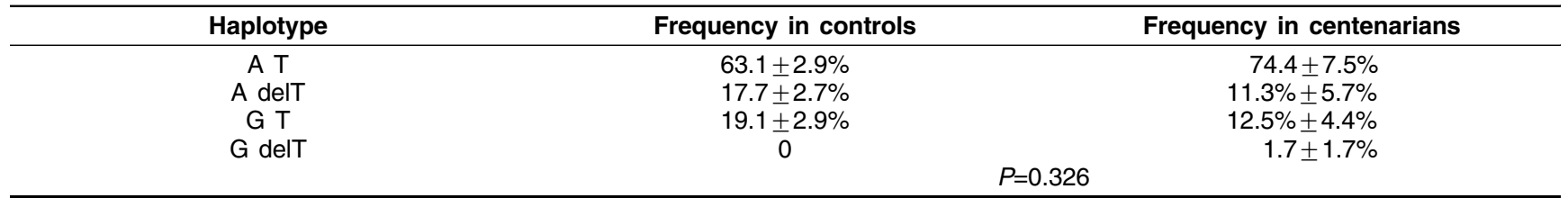


unexpected increase in parameters linked to inflammation, such as the capacity to produce proinflammatory cytokines, ${ }^{35}$ including TNF, which is involved in the induction of apoptosis in a variety of cell types.

Recently, several studies have shown an increased expression of Fas on lymphocytes from elderly donors, which could be due to age-related changes in the susceptibility of these cells to undergo apoptosis. ${ }^{18-21}$ However, few and controversial data are present in literature. Some investigators have reported a decrease of Fas/FasL-induced apoptosis in aged animals, ${ }^{36}$ as well as in human $\mathrm{CD}^{+} \mathrm{T}$ cells reaching replicative senescence. ${ }^{37}$ Accordingly, we have recently reported that an inverse correlation exists between human age and the propensity of lymphocytes to undergo apoptosis induced by oxidative stress. $^{38}$ On the other hand, other authors reported increased apoptosis in lymphocytes from elderly people following activation with anti-CD3, phytohemagglutinin, concanavalin $A,{ }^{19,39}$ or activation with polyclonal mitogens plus anti Fas treatment. 22,40

It is known that polymorphic variants of nuclear loci can play a role in regulating the expression of a given gene. Thus, we explored whether genetic polymorphisms of apoptotic genes such as Fas and FasL exist that could help in explaining the aforementioned phenomena, taking into account that no data exist on their distribution and role in human aging and longevity. In this study we have analyzed the presence of new genetic markers, i.e. -670 and -1377 polymorphisms in Fas promoter, and IVS2nt124 and IVS3nt169 in FasL gene, in a group of 50 Italian centenarians and 86 young donors. No significant differences were found in the genotype and allele frequency between centenarians and controls for all polymorphisms; these data suggest that these polymorphisms likely do not confer any genetic advantage to reach the extreme limit of human life. Moreover, considering the entire group of individuals we have analyzed, our data on Fas gene are in agreement with data reported by Huang et al. for normal Caucasian population. ${ }^{23,24}$ Indeed, the frequencies of the alleles we have analyzed are very similar to those previously reported.

In Northern Italy, the number of female centenarians is higher than males, ${ }^{41}$ and our population well represents this distribution. Thus, we examined the frequencies of Fas and FasL polymorphisms in female subgroups to analyze any possible association with sex. Even if there was a difference in -670 Fas polymorphism, as a higher number of centenarians were homozygous for allele A $(36 \%$ vs $19 \%)$, such difference was not statistically significant likely because of the low number of donors we could analyze. Studies are in course to verify this possibility.

Similar results were observed as far as the -1377 Fas polymorphism is concerned. Indeed, the frequencies we found in centenarians and young donors were extremely similar. However, our results do not exclude a role of such polymorphism in the regulation of Fas expression, as we found a small difference between the two groups in the frequency of $A / A$ genotype that was absent in centenarians. Clearly, due to the low frequency of such a genotype in young donors, a far larger number of subjects is needed to ascertain whether the lack of such a genetic feature could confer an advantage in reaching a far advanced age. The -1377 polymorphism is situated in the binding site for SP. 1 transcription factor, and the presence of $A$ in both alleles could significantly modify the transcription of Fas, with important consequences for the equilibrium of Fas/FasL apoptotic pathway. We are tempted to speculate that presence of the homozygous form of this mutation could be harmful, and so the occurrence of $A / A$ genotype in -1377 position is strongly negatively selected. However, young controls who have this genotype apparently do not show any disorder that can be associated to impaired expression of Fas. This point needs further investigation, and can be at least in part clarified by the direct quantitation of Fas mRNA in lymphocytes or other cells obtained from these subjects, as well as by in vitro analysis of Fas promoter activity with $A$ or $\mathrm{G}$ in position -1377 . Electro-mobility shift assays could further elucidate the eventual modifications occurring in SP-1 binding, when A allele is present in both copies of Fas gene. Finally, it will be crucial to investigate these polymorphisms in subjects of other age-groups.

We analyzed the combined genotypes of Fas and FasL, and found no major differences between centenarians and young donors. The only differences concerned the frequencies of the Fas $(-1377 \mathrm{~A} /-670 \mathrm{~A})$ and $(-1377 \mathrm{~A} /$ $-670 \mathrm{G}$ ) haplotypes (Table $3 \mathrm{~A}$ and $\mathrm{B}$ ), but they could be explained considering the low frequency of $A / A$ genotype at position -1377 . The presence of even one centenarian with this genotype could greatly influence the haplotype estimation, and completely change the analysis. A similar observation was made as far as FasL haplotypes is concerned. Indeed, the only difference regards the fact that among centenarians the haplotype with $G$ in position IVS2nt-124 and delT in position IVSnt169 is represented. Indeed, there is one centenarian with genotype $A / G$ in the position IVS2nt-124 and delT/delT in the position IVS3nt169. However-even if fascinating - we do not think that such a phenomenon has any biological relevance, since the presence of just one young individual with the same genotype would cancel any difference between the groups.

Recently, different authors have analyzed the role of Fas in immunosenescence, and several studies have shown an increased expression of Fas in the elderly, due to an increased number of Fas ${ }^{+}$lymphocytes, ${ }^{18,19,21}$ or increased expression of the gene. ${ }^{20}$ It is well known that Fas is expressed during $\mathrm{T}$ cell activation, and that during a typical immune response Fas-induced apoptosis prevents an excessive clonal expansion. As defects in the Fas gene are related to development of autoimmune diseases (reviewed $i^{14}$ ), the increased expression of Fas antigen on lymphocytes might suggest an enhanced proneness to undergo apoptosis. From this point of view, it can be hypothesized that although there is a large amount of 'memory-preactivated' lymphocytes in the elderly, ${ }^{19}$ the inability to evoke a strong secondary response may be attributable to enhanced apoptosis of these 'old' T cells, in respect to those from young people. A different transcription caused by genetic differences in the promoter of Fas 
could greatly influence the expression of Fas on the surface of the cell, and thus could play an important role in the tendency of $\mathrm{T}$ lymphocytes from elderly people to undergo Fas-induced apoptosis. FasL polymorphisms are located in intronic regions that are clearly not directly related to gene transcription. However, it is possible that they are in linkage disequilibrium with still unknown, polymorphic regions capable of influencing FasL expression. Studies aimed at correlating the expression of Fas and FasL with the genotypes of the subjects we have described in this paper are in course to further investigate this point, and to give new insights into the role and regulation of Fas and FasL during immunosenescence.

\section{Materials and Methods}

\section{Subjects}

A group of 50 centenarians and 86 controls, all living in Northern Italy (Emilia-Romagna Region, located in the Po Valley area) was studied. The mean age of centenarians (44 females, six males) was $100.8 \pm 1.8$ years (mean \pm S.D., range $100-106$ ), whereas the mean age of young donors (36 females, 50 males), randomly chosen among students, medical personnel, and blood donors, was $38.1 \pm 8.5$ years (range $22-54)$. Blood was taken from all donors after informed consent according to the Italian laws, and DNA was extracted according to standardized methods by using a commercially available kit (QIA Amp DNA blood minikit, from Qiagen).

\section{-670 Fas polymorphism typing: analysis of Mval RFLP}

The Mval RFLP was studied by polymerase chain reaction (PCR) amplification followed by Mval restriction enzyme digestion, as previously described. ${ }^{24}$ The primer sequences used for PCR were MvalDir (5'-CTACCTAAGAGCTATCTACCGTTC-3') and MvalRev (5'GGCTGTCCATGTTGTGGCTGC-3'). For each reaction in $25 \mu \mathrm{l}$, $100 \mathrm{ng}$ of DNA template were added to the reaction mixture, containing a final concentration of $200 \mathrm{nM}$ of each primer, $200 \mu \mathrm{M}$ of dNTPs, $1.5 \mathrm{mM} \mathrm{MgCl}_{2}, 50 \mathrm{mM} \mathrm{KCl}_{2}, 10 \mathrm{mM}$ Tris $\mathrm{Cl}(\mathrm{pH} \mathrm{8.5)}$ and $1 \mathrm{U}$ of Taq polymerase (Promega, Madison, WI, USA). The reaction was carried out in a PE 9700 Thermal Cycler (Perkin Elmer, Boston, MA, USA) for 30 cycles, each cycle consisting of $30 \mathrm{~s}$ at $94^{\circ} \mathrm{C}, 30 \mathrm{~s}$ at $62^{\circ} \mathrm{C}$, and $1 \mathrm{~min}$ at $72^{\circ} \mathrm{C}$. The first cycle was preceded by a single step of denaturation at $94^{\circ} \mathrm{C}$ for $6 \mathrm{~min}$, and the last one was followed by a single step of extension at $72^{\circ} \mathrm{C}$ for $10 \mathrm{~min}$. After reaction, $10 \mu \mathrm{l}$ of reaction mixture from each sample were digested with $5 \mathrm{U}$ of Mval restriction enzyme (Roche Biochemicals, Mannheim, Germany) under recommended conditions. The product was loaded onto a $3 \%$ agarose gel and run at $90 \mathrm{~V}$ for $40 \mathrm{~min}$. Two polymorphic alleles, allele $\mathrm{A}$ (233 bp) or allele $G$ (189 bp) were produced depending on the presence of $G$ or $A$ at -670 position of the Fas gene.

\section{- 1377 Fas polymorphism typing}

The -1377 polymorphism was analyzed in part by direct sequencing, and in part by allele specific amplification (ASA). Direct sequencing were carried out by amplification of the region spanning from base -1620 to -1276 respect to the ATG start codon of Fas, using primers Poly2Dir (5'-CCCCTTTTTTTCTCTCTTCCC- $\left.3^{\prime}\right)$ and Poly2Rev (5'-
CCCTGTGTTTTGCATCTGTC-3'). For each reaction in $25 \mu \mathrm{l}, 100 \mathrm{ng}$ of DNA template were added to the reaction mixture, containing a final concentration of $200 \mathrm{nM}$ of each primer, $200 \mu \mathrm{M}$ of dNTPs, $1.5 \mathrm{mM}$ $\mathrm{MgCl}_{2}, 50 \mathrm{mM} \mathrm{KCl}, 10 \mathrm{mM}$ Tris $\mathrm{Cl}(\mathrm{pH} \mathrm{8.5)}$ and $1 \mathrm{U}$ of Taq polymerase. The reaction was carried out in a PE 9700 Thermal Cycler for 30 cycles, with each cycle consisting of $30 \mathrm{~s}$ at $94^{\circ} \mathrm{C}, 30 \mathrm{~s}$ at $56^{\circ} \mathrm{C}$, and $30 \mathrm{~s}$ at $72^{\circ} \mathrm{C}$. The first cycle was preceded by a single step of denaturation at $94^{\circ} \mathrm{C}$ for $6 \mathrm{~min}$, and the last one was followed by a single step of extension at $72^{\circ} \mathrm{C}$ for $10 \mathrm{~min}$. The PCR products were purified using High Pure PCR Product Purification Kit (Roche Biochemicals) and $20 \mathrm{ng}$ of purified DNA were used for sequencing reaction, using BigDye DNA Sequencing Kit (Perkin Elmer). Sequencing reaction was carried out in a PE 9700 Thermal Cycler, under conditions recommended by the customer. Sequenced samples were loaded in a PE ABI Prism 310 Genetic Analyzer (Perkin Elmer) and analyzed using $A B I$ Prism Navigator Software. The two alleles, depending on the presence of $A$ or $G$ at position -1377, were observed as different fluorescence peaks in that position.

For ASA, we followed a previously described method. ${ }^{25}$ Briefly, two primers (F3 and F4) with two mismatches at $3^{\prime}$ position were used, in couple with a common reverse primer (F5). F3 primer is specific for allele ' $G$ ' at position -1377 , and F4 is specific for allele 'A'. For each sample testing two PCR reactions in different tubes were performed; one reaction detected the wild-type $(G)$ allele and the other detected the mutant (A) allele using a specific forward primer and the common reverse primer. PCR products, $393 \mathrm{bp}$ fragments, from both reactions were then run on two different gels because of the exact same size of the two products. If DNA samples were homozygous for the wild-type allele, there would be only products in the reaction containing the wildtype specific primer. Conversely, if a sample was homozygous for mutant allele, a product was only generated in the reaction containing the primer specific for mutant allele. The presence of PCR products in both reactions indicated that the sample was heterozygous. For each reaction in $25 \mu \mathrm{l}, 100 \mathrm{ng}$ of DNA template were added to the reaction mixture, containing a final concentration of $200 \mathrm{nM}$ of each primer, $200 \mathrm{mM}$ of dNTPs, $1.5 \mathrm{mM} \mathrm{MgCl}_{2}, 50 \mathrm{mM} \mathrm{KCl}_{2}, 10 \mathrm{mM} \mathrm{Tris} \mathrm{Cl}$ (pH 8.5) and $1 \mathrm{U}$ of Taq polymerase (Promega). The reaction was carried out in a PE 9700 Thermal Cycler for 30 cycles, with each cycle consisting of $30 \mathrm{~s}$ at $94^{\circ} \mathrm{C}, 30 \mathrm{~s}$ at $62^{\circ} \mathrm{C}$, and $1 \mathrm{~min}$ at $72^{\circ} \mathrm{C}$. The first cycle was preceded by a single step of denaturation at $94^{\circ} \mathrm{C}$ for $6 \mathrm{~min}$, and the last one was followed by a single step of extension at $72^{\circ} \mathrm{C}$ for $10 \mathrm{~min}$.

\section{IVS2nt-124 FasL polymorphism typing}

For ACRS, we followed a previously described method. ${ }^{26}$ The primers used for the PCR were 5140Dir (5'-GCAGTTCAGACCTACATGATTAGGAT- $3^{\prime}$ ) and 5378Rev (5'-CCAATTCTCACCTGTACCTTC- $3^{\prime}$ ). The direct primer contains a mismatch (underlined and bold) that creates an artificial new restriction site in the PCR product; as a consequence the fragment can be cleaved by Fokl in the presence of the allele G. For each PCR reaction in $25 \mu \mathrm{l}, 100 \mathrm{ng}$ of DNA template were added to the reaction mixture, containing a final concentration of $200 \mathrm{nM}$ of each primer, $200 \mathrm{mM}$ of dNTPs, $1.5 \mathrm{mM} \mathrm{MgCl}_{2}, 50 \mathrm{mM}$ $\mathrm{KCl}_{2}, 10 \mathrm{mM}$ Tris $\mathrm{Cl}(\mathrm{pH} 8.5)$ and $1 \mathrm{U}$ of Taq polymerase (Promega). The reaction was carried out in a PE 9700 Thermal Cycler for 30 cycles, with each cycle consisting of $30 \mathrm{~s}$ at $94^{\circ} \mathrm{C}, 30 \mathrm{~s}$ at $62^{\circ} \mathrm{C}$, and $1 \mathrm{~min}$ at $72^{\circ} \mathrm{C}$. The first cycle was preceded by a step of denaturation at $94^{\circ} \mathrm{C}$ for $6 \mathrm{~min}$, and the last one was followed by a step of extension at $72^{\circ} \mathrm{C}$ for $10 \mathrm{~min}$. Ten $\mu$ l of PCR product was digested with $1 \mathrm{U}$ of Fokl under recommended conditions and loaded on a $3 \%$ agarose gel. If allele $\mathrm{G}$ was present, the digestion generates a 210 bp fragment; conversely if $A$ allele was present there was not any digestion and the 239 bp fragment remained intact. 


\section{IVS3nt169FasL polymorphism typing}

As for IVS2nt-124 polymorphism, this one was analyzed with ACRS. The primers used for the PCR are 6247Dir (5'-AGGAAAGGACTTCAAAGCCTA-3') e 6231Rev (5'-TTGATGCATCACAGAATTTCGTC$\left.3^{\prime}\right)$. In this case the reverse primer contains a mismatch (underlined and bold) that creates an artificial new restriction site for Hincll in the PCR product. For each PCR reaction in $25 \mu \mathrm{l}, 100 \mathrm{ng}$ of DNA template were added to the reaction mixture, containing a final concentration of $200 \mathrm{nM}$ of each primer, $200 \mathrm{mM}$ of dNTPs, $1.5 \mathrm{mM} \mathrm{MgCl}_{2}, 50 \mathrm{mM}$ $\mathrm{KCl}_{2}, 10 \mathrm{mM}$ Tris $\mathrm{Cl}(\mathrm{pH} \mathrm{8.5)}$ and $1 \mathrm{U}$ of Taq polymerase (Promega). The reaction was carried out in a PE 9700 Thermal Cycler for 30 cycles, with each cycle consisting of $30 \mathrm{~s}$ at $94^{\circ} \mathrm{C}, 30 \mathrm{~s}$ at $60^{\circ} \mathrm{C}$, and $30 \mathrm{~s}$ at $72^{\circ} \mathrm{C}$. The first cycle was preceded by a step of denaturation at $94^{\circ} \mathrm{C}$ for $6 \mathrm{~min}$, and the last one was followed by a step of extension at $72^{\circ} \mathrm{C}$ for $10 \mathrm{~min}$. Ten $\mu$ l of PCR product is digested with $1 \mathrm{U}$ of Hincll under recommended conditions and loaded on a $3 \%$ agarose gel. If allele $\mathrm{T}$ is present, the digestion generates a $162 \mathrm{bp}$ fragment; if delT allele is present the $185 \mathrm{bp}$ band was present on the gel.

\section{Statistical Analysis}

The distribution of the -670 and -1377 Fas genotypes, and that of IVS2nt-124 and IVS3nt169 FasL genotypes in centenarians was compared to that in controls using the $\chi^{2}$ test $(3 \times 2$ contingency table with Monte Carlo option); differences in allele frequency were analyzed by z-test using SPSS 10 software operating under Windows ME. Genetic analysis regarding haplotype frequency estimation was performed according to Guo and Thompson, ${ }^{27}$ using Arlequin software (by Drs. L Excoffier, S Schneider, D Roessli, University of Geneva, Switzerland, downloaded at http://lgb.unige.ch/arlequin/software/).

\section{Acknowledgements}

We acknowledge Professor R Lockshin (St. John's University, Jamaica, NY), Dr. M Bonafè (Univ. of Bologna) and Professor D Lio (Univ. of Palermo) for critical comments and helpful suggestions. This work has been supported by grants from MURST (Cofin 1999) to A Cossarizza.

\section{References}

1. Monti D, Grassilli E, Troiano L, Cossarizza A, Salvioli S, Barbieri D, Agnesini C, Bettuzzi S, Ingletti MC, Corti A and Franceschi C (1992) Senescence, immortalization and apoptosis: an intriguing relationship. Ann. N.Y. Acad. Sci. 663: $70-82$

2. Monti D, Troiano L, Grassilli E, Agnesini C, Tropea F, Barbieri D, Capri M, Salvioli S, Ronchetti I, Bellomo G, Cossarizza A and Franceschi C (1992) Cell proliferation and cell death in immunosenescence. Ann. N.Y. Acad. Sci. 663: $250-261$

3. Monti D, Troiano L, Tropea F, Grassilli E, Cossarizza A, Barozzi D, Pelloni MC, Tamassia MG and Franceschi C (1992) Apoptosis - Programmed cell death: a role in the aging process? Am. J. Clin. Nutr. 55: 1208s-1214s

4. Cossarizza A, Barbieri D and Londei M (1995) T cell repertoire usage in humans, from newborns to centenarians Int. Rev. Immunol. 12: 41-55

5. Franceschi C, Monti D, Barbieri D, Salvioli S, Negro P, Capri M, Guido M, Azzi R, Sansoni P, Paganelli R, Fagiolo U, Baggio G, Donazzan S, Mariotti S, D'Addato S, Gaddi A, Ortolani C and Cossarizza A (1995) Immunosenescence in humans: deterioration or remodelling? Int. Rev. Immunol. 12: 57-74

6. Franceschi C, Monti D, Sansoni P and Cossarizza A (1995) The immunology of exceptional individuals: the lesson of centenarians. Immunol. Today 16: 12-16
7. Fagnoni FF, Vescovini R, Mazzola M, Bologna G, Nigro E, Lavagetto G, Franceschi C, Passeri M and Sansoni P (1996) Expansion of cytotoxic CD8+ CD28 - T cells in healthy ageing people, including centenarians. Immunology 88: $501-507$

8. Pawelec G, Adibzadeh M, Rehbein A, HahnelK, WagnerW and Engel A (2000) In vitro senescence models for human T lymphocytes. Vaccine 18: 1666-1674

9. Itoh N, Yonehara S, Ishii A, Yonehara M, Mizushima SI, Sameshima M, Hase A, Seto $Y$ and Nagata S(1991) The polypeptide encoded by the cDNA for human cell surface antigen Fas can mediate apoptosis. Cell 66: 233-243

10. Cory S (1994) Fascinating death factor. Nature 367: 317-318

11. Ju ST, Panka DJ, Cul H, Ettinger R, El-Khatib M, Sherr DH, Stanger BZ and Marshak-Rothstein A (1995) Fas(CD95)/FasL interaction required for programmed cell death after T-cell activation. Nature 373: 444-448

12. Nagata $S$ and Golstein $P$ (1995) The Fas death factor. Science 267: 1449 - 1456

13. Lynch DH, Ramsdell F and Alderson MR (1995) Fas and Fas L in the homeostatic regulation of immune responses. Immunol. Today 16: 569-574

14. Lenardo M, Chan KM, Hornung F, McFarland $H$, Siegel R, Wang J and Zheng $L$ (1999) Mature T lymphocyte apoptosis-immune regulation in a dynamic and unpredictable antigenic environment. Annu. Rev. Immunol. 17: 221-253

15. Nagata S (1999) Fas ligand-induced apoptosis. Annu. Rev. Genet. 33: 29-55

16. Depraetere V and Golstein P (1997) Fas and other cell death signaling pathways. Sem. Immunol. 9: 93-107

17. Peter ME and Krammer PH (1998) Mechanisms of CD95 (APO-1/Fas)-mediated apoptosis. Curr. Opin. Immunol. 10: 545-551

18. Phelouzat MA, Arbogast A, Laforge T, Quadri RA and Proust JJ (1996) Excessive apoptosis of mature $T$ lymphocytes is a characteristic feature of human immune senescence. Mech. Ageing Dev. 88: 25-38

19. Potestio M, Pawelec G, Di Lorenzo G, Candore G, D'Anna C, Gervasi F, Lio D, Tranchida G, Caruso C and Romano GC (1999) Age-related changes in the expression of CD95 (AP01/FAS) on blood lymphocytes. Exp. Gerontol. 34: $659-673$

20. Gupta S (2000) Molecular and biochemical pathways of apoptosis in lymphocytes from aged humans. Vaccine 18: 1596-1601

21. Fagnoni FF, Vescovini R, Passeri G, Bologna G, Pedrazzoni M, Lavagetto G, Casti A, Franceschi C, Passeri M and Sansoni P (2000) Shortage of circulating naive $\mathrm{CD} 8+\mathrm{T}$ cells provides new insights on immunodeficiency in aging. Blood 95: $2860-2868$

22. Aggarwal S and Gupta S (1998) Increased apoptosis of T cell subsets in aging humans: altered expression of Fas (CD95), Fas ligand, Bcl-2, and Bax. J. Immunol. 160: 1627-1637

23. Huang QR, Morris D and Manolios N (1997) Identification and characterization of polymorphisms in the promoter region of the human Apo-1/Fas (CD95) gene. Mol. Immunol. 34: 577-582

24. Huang QR, Danis V, Lassere M, Edmonds J and Manolios N (1999) Evaluation of a new Apo-1/Fas promoter polymorphism in rheumatoid arthritis and systemic lupus erythematosus patients. Rheumatology 38: 645-651

25. Huang QR and Manolios N (2000) Investigation of the -1377 polymorphism on the Apo-1/Fas promoter in systemic lupus erythematosus patients using allelespecific amplification. Pathology 32: 126-130

26. Bolstad AI, Wargelius A, Nakken B, Haga H-J and Jonsson R (2000) Fas and Fas Ligand gene polymorphisms in primary Sjögren's Syndrome. J. Rheumatol. 27: 2397-2405

27. Guo SW and Thompson EA (1992) Performing the exact test of Hardy-Weinberg proportion for multiple alleles. Biometrics 48: $361-372$

28. Mariotti S, Sansoni P, Barbesino G, Caturegli P, Monti D, Cossarizza A, Giacomelli T, Passeri G, Fagiolo U, Pinchera A and Franceschi C (1992) Thyroid and other organ-specific autoantibodies in healthy centenarians. Lancet 339: $1506-1508$

29. Sansoni P, Cossarizza A, Brianti V, Fagnoni F, Snelli G, Monti D, Marcato A, Passeri G, Ortolani C, Forti E, Fagiolo U, Passeri M and Franceschi C (1993) Lymphocyte subsets and natural killer cell activity in healthy old people and centenarians. Blood 80: 2767-2773

30. Paganelli R, Scala E, Rosso R, Cossarizza A, Bertollo L, Barbieri D, Fabrizi A, Lusi EA, Fagiolo U and Franceschi C (1996) A shift to THO-type cytokine production by $C D 4+$ cells in human longevity: studies in two healthy centenarians. Eur. J. Immunol. 26: 2030-2034

31. Cossarizza A, Ortolani C, Monti D and Franceschi C (1997) Cytometric analysis of immunosenescence. Cytometry 270: 297-314 
32. Wack A, Cossarizza A, Heltai S, D'Addato S, Franceschi C, Dellabona P and Casorati G (1998) Age-related increase of clonal expansions in human peripheral blood T cells: CD8+are more affected than CD4+, irrispective of their CD45RA, CD45R0 and CD28 expression. Int. Immunol. 10: 1281-1288

33. Bagnara GP, Bonsi L, Strippoli PL, Bonifazi F, Tonelli R, D'Addato S, Paganelli R, Scala E, Fagiolo U, Monti D, Cossarizza A, Bonafé M and Franceschi C (2000) Hemopoiesis in healthy old people and centenarians: well-maintained responsiveness of $C D 34+c e l l s$ to hemopoietic growth factors and remodeling of cytokine network. J. Gerontol. 55A: B61-B66

34. Gerli R, Monti D, Bistoni O, Mazzone AM, Cossarizza A, Di Gioacchino M, Cesarotti MEF, Mantovani A, Franceschi C and Paganelli R (2000) Chemokines, sTNF-Rs and SCD30 serum levels in healthy aged people and centenarians. Mech. Ageing Dev. 121: 37-46

35. Fagiolo U, Cossarizza A, Scala E, Fanales-Belasio E, Ortolani C, Cozzi E, Monti D, Franceschi C and Paganelli R (1993) Increased cytokine production in mononuclear cells of healthy elderly people. Eur. J. Immunol. 23: 2375-2378

36. Zhou T, Edwards CK and Mountz JD (1995) Prevention of age-related T cell apoptosis defect in CD2-fas-transgenic mice. J. Exp. Med. 182: 129-137
37. Spaulding C, Guo W and Effros RB (1999) Resistance to apoptosis in human $\mathrm{CD} 8+\mathrm{T}$ cells that reach replicative senescence after multiple rounds of antigenspecific proliferation. Exp. Gerontol. 34: 633-644

38. Monti D, Salvioli S, Capri M, Malorni W, Straface E, Cossarizza A, Botti B, Piacentini M, Baggio G, Barbi C, Valensin S, Bonafè M and Franceschi C (2000) Decreased susceptibility to oxidative stress-induced apoptosis of peripheral blood mononuclear cells from healthy elderly and centenarians. Mech. Ageing Dev. 121: 239-250

39. Herndon FJ, Hsu HC and Mountz JD (1997) Increased apoptosis of CD45RO- T cells with aging. Mech. Ageing Dev. 94: 123-134

40. Aggarwal S, Gollapudi S and Gupta S (1999) Increased TNF-alpha-induced apoptosis in lymphocytes from aged humans: changes in TNF-alpha receptor expression and activation of caspases. J. Immunol. 162: 2154-2161

41. Motta L, Receputo $G$ and Franceschi $C$ for the Italian Multicentric Study on Centenarians. (1995) I centenari in Italia: aspetti biologici e clinicoepidemiologici. In: Atti del Congresso della Società Italiana di Medicina Interna. Vol. 2, pp 117-218 (Roma: L. Pozzi Publ.). 